\title{
CULTURES OF MEMORY, LANDSCAPES OF FORGETTING: THE CASE STUDY OF THE PARTISAN MEMORIAL CEMETERY IN MOSTAR
}

KRISTINA ILIĆ

Antuna Stipančića 9, Zagreb

kristinailic.fpzg@gmail.com

iD orcid.org/0000-0002-6495-8926

NEVENA ŠKRBIĆ ALEMPIJEVIĆ

Faculty of Humanities and Social Sciences, Zagreb

Ethnology and Cultural Anthropology Department

Ivana Lučića 3, Zagreb

nskrbic@ffzg.hr

iD orcid.org/0000-0002-8653-7954
DOI: $10.17234 /$ SEC.29.3

Original scientific paper

Received: 7. 5. 2017.

Accepted: 1. 7. 2017.

This article is an open access article distributed under the terms and conditions of the CC BYNC-ND 4.0 license.

The war and political turmoil in Bosnia and Herzegovina in the 1990s had an impact on the creation of new cultural and political identities, but also mnemonic systems. In order to delineate the social dynamics we considered the changes that the spaces shaped during socialism as places of memory had gone through. By researching that process, the creation of the landscapes of forgetting is being analysed. The paper focuses on the Partisan Cemetery, a monument from 1965 in Mostar. It sheds light on the changes in spatial planning practices, but also everyday practices related to the memorial cemetery. In conclusion, younger generations of Mostar residents'narratives on the Partisan Cemetery and its (possible) usages are analysed.

Keywords: cultures of memory, landscapes of forgetting, socialist monuments, Mostar, Partisan cemetery

\section{ON MONUMENTS FROM THE PERSPECTIVE OF ETHNOLOGY AND CULTURAL ANTHROPOLOGY ${ }^{1}$}

Social memory is enacted in its materialisations. For the transfer of desirable attitudes about what a group, a community, or a nation should

\footnotetext{
${ }^{1}$ The paper is based on the results of an ethnographic research conducted by Kristina Ilic in the course of writing her diploma thesis entitled: "Historical and cultural anthropological analysis of Croat-Bosniak conflict in Mostar (1992 - 1995)", which took shape under the mentorship of Nevena Škrbić Alempijević and Hrvoje Klasić (2016).
} 
remember from its past and what not, from the top of the political hierarchy to all other social domains to take place, it is necessary for the reminders of that past to become a part of our everyday life, namely they need to be materialised, objectified, and given space in the public sphere. In this process, monuments have an important role: they give concrete expression and shape to the abstract representations of history, setting them in the public space, making them a part of human experience of a place, wherein passers-by from different temporal levels, namely contemporary and the one that the monument refers to, coexist (Frykman 2004). Erecting monuments is one of the strategies through which the memory dimension is represented as an inseparable determinant of the place as a culturally significant space (c.f. Čapo and Gulin Zrnić 2011:33-34). Thus the monument becomes a device for creating the memory place, the space of being and belonging, that is constituted as an expression of ideology, shaped by discourse, but also by physical behaviours, movement, and relationship between the people and the material culture (Nora 1996). It is precisely this interaction between materiality and the people who create it, or come into contact with it, that is essential for the study of monuments in ethnology and cultural anthropology. People's points of view, narrations, practices, affects, and interests, inscribed and ascribed, but also encouraged by monuments, open the door for researchers to consider the wider social and political context, both in the moment when the monument is created and in all other later moments of its usage, reinterpretation, or forgetting.

Forgetting is a process immanent to social memory construction, in equal measure intentional, politically and culturally determined as the memory itself. The decision based on which layers from the total historical inventory are to be put in the background, not mentioned, or removed in the period when they are proclaimed unsuitable, is reflected and can be seen in the spatial planning policies, especially those related to how the monuments are treated. Thus the analysis of memorial places, their usages and destinies uncovers also the topographies of forgetting (Connerton 2009:99). In terms of time, manifestations of forgetting are most noticeable during breaks in history, when there is a shift in political system subsequent to which the historical imagery is fundamentally redefined in order to reshape the collective identity. In terms of space, forgetting becomes most evident in shifting the focus towards the interventions in the spatial toponymy, i.e. 
changing streets and squares' names and erecting or removing monuments from the public space (Rihtman-Auguštin 2000).

This study looks at precisely such topography of forgetting by researching policies and cultures that lead to erecting and usage of monuments as well as the interventions that deface them. The landscape that is explored in the study becomes evident with the break-up of the former Socialist Federal Republic of Yugoslavia and the constitution of a new, independent state of Bosnia and Herzegovina. Namely, at the time when two symbolically opposed memory systems, which were used to legitimise the respective political systems, clash. The focus is on Mostar, the administrative centre of Herzegovina-Neretva Canton in the period following the 1990s war and the signing of the Dayton Peace Agreement. The case study that is taken as the basis for our analysis focuses on the Partisan cemetery memorial and landscape complex, the work of Bogdan Bogdanović, a famous Serbian architect, which was erected at the Bijeli brijeg quarter in West Mostar in 1965. This is a memorial cemetery covering around $5000 \mathrm{~m} 2$, divided into six terraces that are dominated by memorial plates dedicated to Partisan fighters who died defending the city during WWII. The memorial complex had a prominent role in constructing and perpetuating the adequate politics of remembering in Yugoslavia of the time, bearing in mind that the space is an anchor for the topos of the Partisan as a hero of socialism and the memory of the National Liberation War as the foundations of statehood. Certain aspects of the realm of memory production were also connected with the local domain, namely the concept embedded in the narrative about a multiethnic and multireligious Mostar and the equality of all "nations and nationalities", as the rhetoric prevailing at the time would put it, that make up a city. The intention of the Partisan cemetery initiators and creators was to make it part and parcel of Mostar daily life, a space for spending leisure time, free of the burden of being used exclusively ceremonially as a place and a memory. However, in the 1990s, with the disintegration of socialist Yugoslavia and in the light of war developments, the statehood myth of "brotherhood and unity" was replaced by symbols referring to the ethnic and religious distinctiveness of ethnic communities. Thus the places of memory, which were set up within the overthrown political system became controversial spaces, reminders of the past which nationalities, at least in their official rhetoric, wish to remember 
no more. Consequently, the transformation into the landscape of forgetting engulfed the Partisan memorial cemetery complex, too. It is this particular process that this paper wishes to problematise. We used the qualitative methodology in our research comprising of observation and ethnographic descriptions of the Partisan cemetery and subsequent interventions in that space; the discourse analyses from professional literature dealing with Bogdanović's project and the monument design; followed by media coverage analysis; and the interviews with the residents of Mostar. In the interviews we focused mainly on the younger generations since we were interested to see how the Partisan cemetery is being conceptualised and given meaning by those city residents who did not have the life experience related to the ways in which the space had been used in socialism, in the period immediately after the monument complex was erected.

The following questions were the starting point in our research: What happens to the places of memory at the moment when they are no longer unwanted? How is forgetting being actualised in space? Are there any users of the urban public space who "want to remember", i.e. incorporate the different layers of local and national past into their experiences, usages, and visions for the future of the city? How do younger generations, who do not have autobiographical experience of the life in socialism, relate to the Partisan cemetery? However, in order to shed light on tactics and effects of forgetting, first we need to point to the processes of memory creating and its actualisation in the urban landscape. In the next chapter we shall delve into how, why, and for whom the Partisan cemetery originated.

\section{POLITICS AND POETICS OF MEMORY PLACE CREATION AND DISSOLUTION}

One of the factors to consider, in trying to understand the mechanism through which evoking the past is being immortalized and materialised in space, is the one that pertains to the creator of the memorial space. Therefore, we shall devote our attention to the following question: What did the Partisan cemetery represent to Bogdan Bogdanović himself, both in its concept and the meanings that he ascribed to it, and in its enactment? In this way, the author of the space intervention will lend his perspective to our attempt to comprehend the monument politics, inevitably pointing to 
the political, economic, and social context that had an impact on the project design and its realisation. Bogdan Bogdanović (1922 - 2010) first built his career as an architect, but was also a distinguished artist, philosopher, and politician (Bogdanović and Jovičić 2002:81). He primarily taught at the Belgrade University Faculty of Architecture, (Bogdanović 2001), but he also supported informal architecture schools like the one in Mali Popović (Bogdanović and Jovičić 2002:81). From 1982 to 1986 he was the mayor of Belgrade, and in 1987 he chose to step down from political office and began to systematically and actively criticise the Slobodan Milošević's regime (c.f. Bogdanović 1988).

When analysing the creation of memory places, it is important to consider the way in which the author defined and approached the city and urban space design. Many of his numerous texts dealt with this concept, using Belgrade as an example in particular. In his works a desirable city model is the one that is open, multinational, multireligious, multicultural, cosmopolitan (c.f. Bogdanović 2001:23). In Bogdanović's critique of the monolithic Belgrade, he emphasises:

“...in terms of its size, Belgrade should be, like Vienna, multinational, multireligious, multiculti, etc. but Belgrade is not. (...) Belgrade is a monolithic city: one language, one nation, one religion... in the past two decades Belgrade has been disconnected from being multinational, multiethnic, multilingual. A monolingual city of two million is a monster."2

Referring to the multicultural nature of big cities in the European context, Bogdanović concludes that the city development in the states that used to be the constituents of the Socialist Federal Republic of Yugoslavia, depends to a great extent on whether the new states are immured in their "national-autism", that is to say whether they make a departure from the open and honest acceptance of multiculturalism in the region (Bogdanović 2001:23). The multiethnic and multireligious concepts were a fertile ground for many of Bogdanović's ideas, including the one about the Partisan

\footnotetext{
${ }^{2}$ Available at http://www.prometej.ba/clanak/kultura/bogdan-bogdanovic-sanjam-osvijetu-bez-spomenika-1411 (accessed on 16/2/17).
} 
cemetery. The Partisan cemetery is all the more remarkable for being constructed in Mostar, which prior to the war in the 1990s was associated with the concepts of multiethnicity and coexistence of different cultures that have left their mark in it throughout history. Bogdanović intended to emphasise the concept of multiethnicity when he designed the Partiza. ${ }^{3}$ The monument's purpose was to provide Mostar residents, who fell in battle during the National Liberation War, with an afterlife without their memorial plates being separated in space or marked differently depending on their religious or ethnic background.

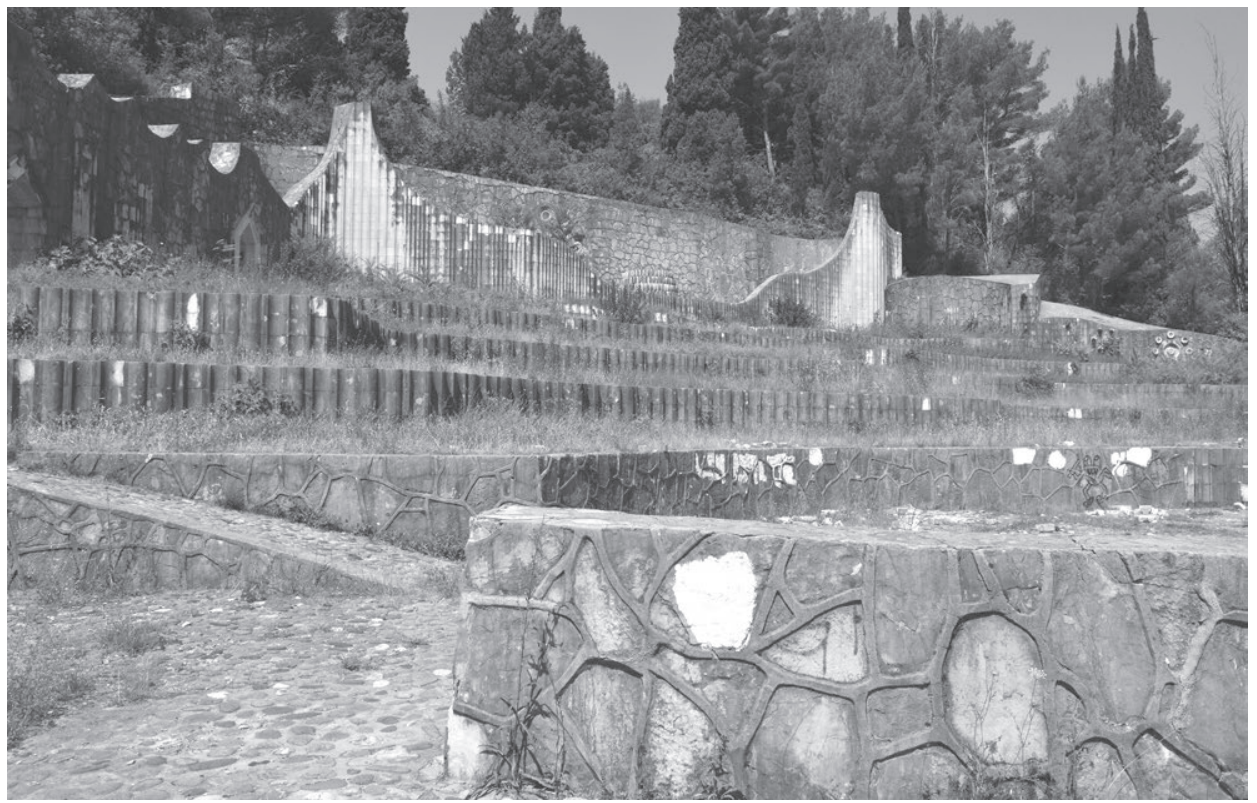

Figure 1: Partisan cemetery (Photo by Katarina Vasilj, 10/07/17)

The Partisan memorial cemetery was constructed at the Mostar quarter of Bijeli brijeg, on a hilltop abundant with green space. It is a memorial complex constructed in order to materialise the memory of the fighting between the Yugoslav People's Army and the German Wehrmacht towards the end of WWII, i.e. the memory of partisans who participated in the

\footnotetext{
${ }^{3}$ Colloquial name for the Partisan cemetery.
} 
liberation of Mostar on 14 February $1945 .{ }^{4}$ In this regard, the monument materialises the memory of the National Liberation War and symbolises antifascism (c.f. Markovina 2014). The heroism and sacrifice of young partisans is commemorated by stone memorial plates, as a part of the memorial cemetery, whose shape resembles a cut down tree that is a symbolic representation of a life suddenly cut short. The plates are located at the upper terraces of the monument. Initially there were more than eight hundred of them. ${ }^{5}$ However, the Partisan memorial cemetery is more than just an agglomeration of headstones. It is an architecturally complex monument occupying 5000 $\mathrm{m} 2$, whose levels ascend in sequence (ibid.:188). The author's intention is to make the monument an authentic part of the Mostar area by intertwining his intervention with the landscape in which it is created, allowing them to shape each other. In designing the monument, Bogdanovic has (re)created the Mostar landscape and persevered with making the specificities of the region a part of his concept of the Partisan cemetery. This tendency is evident in the very choice of material for building the memorial complex, which is characteristic to Herzegovina climate, e.g. using river pebbles to make the pathways (c.f. Markovina 2014).

The Partisan cemetery was conceived as the Mostar's "city of the dead" which signifies the author's mourning the death but also celebrating the life of the young people who took part in the National Liberation War. At the same time, one of Bogdanović's goals was to enable the visitors to experience the space not exclusively as a cemetery, but also as a place for leisure time which can be connected with various cultural practices (c.f. ibid.:189). Upon its creation, the Partiza was awarded the epithet of "Little

\footnotetext{
${ }^{4}$ The plates from the Partisan cemetery bear names, surnames, places of birth and places and years of death of the participants of the armed conflicts that took place around Mostar. Radmilo Braca Andrić, Mostar mayor from 1969 to 1974, said that he had the data confirming the identifications on the plates. However, statements about whether some of those fallen here have also been buried here, differ. C.f.: https://www.youtube.com/ watch?v=7aAVVrfqHvo (accessed on 16/2/17).

${ }^{5}$ The exact number of plates at the memorial cemetery is difficult to ascertain today because the cemetery (and the plates therein) had been devastated many times.

${ }^{6}$ Available at http://lupiga.com/vijesti/bogdan-bogdanovic-mostarski-grad-mrtvih-imostar-mrtvi-grad (accessed on 16/2/17).
} 
Mostar", ${ }^{7}$ which was ascribed to it by the author himself. This characteristic of the monument is associated with Mostar as a place that has been multiethnic and multireligious during the course of history. This becomes most apparent in view of the stone plates, which are a component of the memorial cemetery, that have "Muslim, Croatian and Serbian names"8 of those who fell in battle written on them; the monument's author talks about it at length in his text entitled "Mostar city of the dead and Mostar - a dead city"

“(...) in constructing the Mostar acro-necropolis, a deep, inner fire swept over me. The task at hand was by no means easy or straightforward but I was getting on with it without nausea or fatigue, in fact, I was overwhelmed by a new way of comprehending life and death. Perhaps it sounds absurd, but it was as if I was hoping to impart some of my secret joy to my 'new friends', whose names - Muslim, Serbian, and Croatian - only just began taking shape on the necropolis terraces. Their little afterlife city, as I had promised to their families, was overlooking the very heart of Mostar old city". ${ }^{9}$

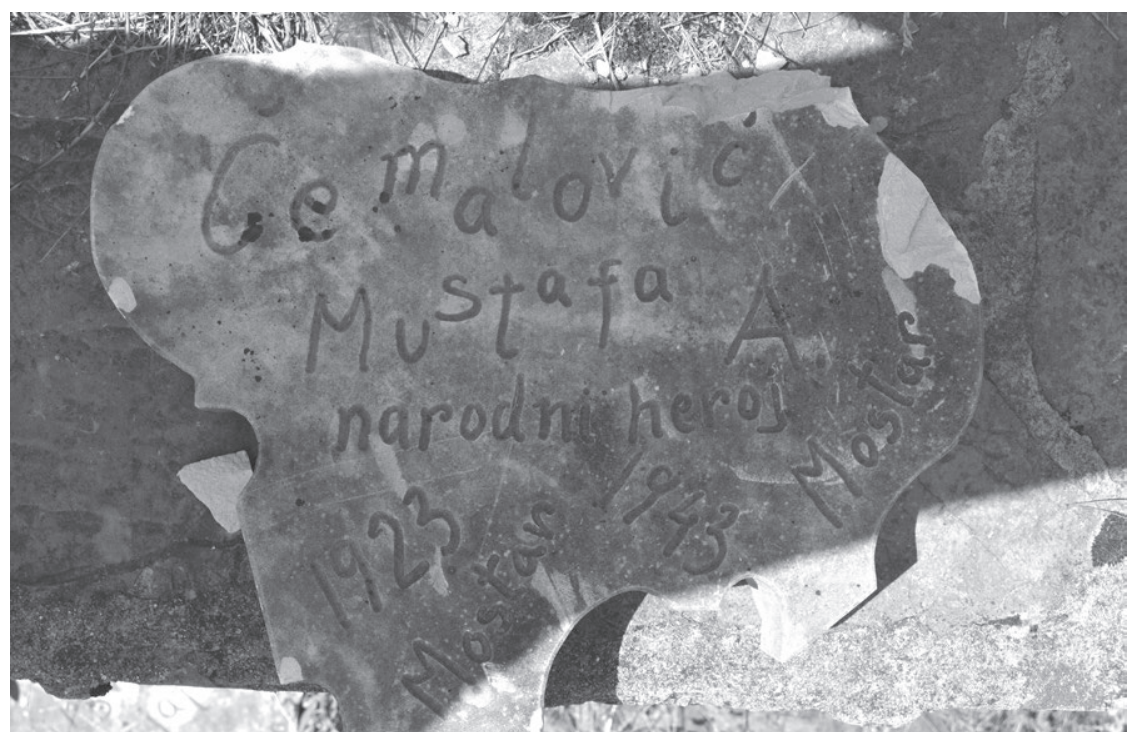

Figure 2: A plate with the name of Mustafa Čmalovic at the Partisan cemetery (Photo by Katarina Vasilj, 10/07/17)

\footnotetext{
${ }^{7}$ Ibid.

${ }^{8}$ Ibid.

${ }^{9}$ Ibid.
} 
Considering the creation and enactment of the Partisan cemetery as a place of memory would not be complete without also considering the position of the city spatial planning and mnemonic policy makers of the time, the issue of the initiative for putting the monument up, its commissioning, and financing. The initiator of the Partisan cemetery construction was Džemal Bijedić, Yugoslav politician and a member of the Communist Party. In 1959, due to Bijedić's activities, the initiative committee for the construction of the Mostar monument was constituted. A Mostar based company Parkovi [engl. Parks] was involved in shaping the memory landscape. The task of designing and constructing the monument was entrusted to Bogdan Bogdanović, by then a well-known Yugoslav architect. ${ }^{10}$ Official ceremonial unveiling of the monument took place on 25 September 1965, and it was unveiled by Josip Broz Tito.

The design and the construction of the monument complex were dictated from the top of the political hierarchy with a clear ideological message, which legitimized the incumbent political system by invoking the heritage of the National Liberation War. However, the spatial planning policy makers devoted a lot of attention to presenting the project as a space that would be co-created by all Mostar residents. Therefore, in designing the Partisan cemetery special attention was given to the ways in which the visitors could use the monument (Bogdanović 2001:18-19). Bogdanović intended for the monument to become a crucial part of the city environment as well as its practices and routes. The communication between Mostar residents and the monument, as shown by Sonja Leboš, the author of "Bogdan Bogdanović - The Doomed Architect" exhibition, was in fact established (Leboš 2012:25). The studies that focus on monument usages point out that the Partisan cemetery functioned as an "intrinsic part of Mostar's urbanological complex", ${ }^{11}$ but also as the space for daily life, although defined as a memory place.

The events connected with the Partisan cemetery during and after the 1990s war provide an insight into a different face of monument politics, as

\footnotetext{
${ }^{10}$ Available at https://www.youtube.com/watch?v=eDZZoitB-30 (accessed on 16/2/17).

${ }^{11}$ Available at http://www.lupiga.com/vijesti/uz-ukletog-neimara-socijalistickimodernizam-imao-je-humanisticku-viziju-da-se-stvari-grade-kako-bi-ljudi-zivjeli-boljei-dostojanstvenije (accessed on 16/2/17).
} 
well as the way in which the history episode that the monument refers to is remembered. During this period the monument complex was vandalized on multiple occasions and abandoned to intentional collective amnesia. ${ }^{12}$ The Partisan cemetery was first damaged by heavy shelling during the war in $1992 .{ }^{13}$ Since he probably considered the act of devastation a part of the life story of the Mostar monument, and Mostar in general, Bogdanović did not seek to have it completely rehabilitated and restored to its pre-war condition. ${ }^{14}$ Regarding this work as well as his other works "unfinished monuments" (c.f. Bogdanović 2001) that are materialised in communication with their environment and are constantly undergoing contextual change, Bogdanović considered the traces of war devastation, engraved in the monument texture, a part of the story about the city of Mostar.

Nevertheless, it is necessary to make a distinction between the author's decision to have the monument materialised as a kind of palimpsest that enables different layers of the city's history to be seen, including recent war destruction, and its neglect, disrepair, and forgetting as a segment of Mostar cultural heritage.

The following chapters are an attempt to provide answers to the following questions: How do Mostar residents treat the Partisan cemetery and the memory that it materialises today? What roles did different political players and the war play in the city during the 1990s? And finally, what meanings have been assigned to the monument in the post-socialist period, which places considerable emphasis on the politics of forgetting. In order to shed light on the breaks in the politics of remembering that had an impact on the current state and treatment of the Partisan cemetery, it is necessary to give an outline of the period when a great shift in mnemonic systems occurred, primarily within the context of the 1990s war and the subsequent division of the city, both symbolic and very physical, that is visible in the space.

\footnotetext{
${ }^{12}$ Ibid.

${ }^{13}$ Available at http://impulsportal.net/index.php/kolumne/drustvo/919-partizanskispomenik-mostar-u-malom-replika-grada-na-neretvi (accessed on 16/2/17). See note 4: https://www.youtube.com/watch?v=7aAVVrfqHvo (accessed on 16/2/17).

${ }^{14}$ Available at http://www.lupiga.com/vijesti/uz-ukletog-neimara-socijalistickimodernizam-imao-je-humanisticku-viziju-da-se-stvari-grade-kako-bi-ljudi-zivjeli-boljei-dostojanstvenije_(accessed on 16/2/17).
} 


\section{POLITICS OF REMEMBERING IN CONTEMPORARY MOSTAR}

In order to understand the contemporary Mostar context, especially regarding the changes in the memory place, it is important to take into account the city's past as well as the political and social turmoil that it has gone through from the time when the monument complex was unveiled until today. In doing so, we shall focus on Mostar's recent past, namely the war in Bosnia and Herzegovina that lasted from 1992 to 1995, and took place in Mostar among other places. This event represents a break in history in line with the way in which the syntagm is defined by Tihomir Cipek, a Croatian political scientist (c.f. Cipek 2007). The above mentioned author considers breaks in history to be the key events according to which people find their bearing, adopt attitudes which legitimize the current political system and create the cultures of memory that are active in the present (Cipek and Bosto 2009:7). It can be seen from the contemporary narratives of Mostar residents on the Partisan cemetery that the war events of the 1990s represented such a break in history due to which the politics of remembering was reshaped on altered foundations. Namely, every narration about the Partiza today included a mention of the war events, and the subsequent division of the city on the basis of ethnicity, as a decisive factor in the recent practices of (non)use or experience of the memorial complex in daily life. Therefore, we shall give a short overview of how Mostar was divided into east and west, on the mechanisms that perpetuate this division, and ways in which the break in history manifests itself in the space of the Partisan cemetery in modernity.

The history of the current division of Mostar into its east and west parts, is tangible on the symbolic level, but also in the city materiality, and is vividly imprinted on the residents' consciousness. The topic was researched by the representatives of different scientific disciplines, mainly historians, political scientists, sociologists, but also ethnologists and cultural anthropologists. Thus, Sanja Puljar D'Alessio dealt with the cultural and social determinants behind the partition of Mostar in the 1990s, which led to exclusively ascribing city symbols and public spaces, which were until then common to both, to either one or the other political option, i.e. 'side' of Mostar (Puljar D’Alessio 2011). During researching Mostar as a disputable 
space, Puljar D'Alessio says that three ethnic groups were represented in highest numbers, namely: Bosniaks, Serbs, and Croats. ${ }^{15}$ None of the groups had strong dominance over the other two in the urban space, at least not in the official rhetoric, especially because the identification strategy, dictated from the top of the political hierarchy, insisted upon superimposing the belonging to former Yugoslavia as the umbrella category on all the three groups (ibid.:227). However, a part of Mostar population fostered the sense of belonging to their national and ethnic group, at least in the private sphere, regardless of the dictates coming from the top of the political ladder. The feeling of belonging was given a collective form and platform for public expression in the 1990s, due to the political turmoil. Armed conflict in Mostar (1992-1995) resulted in a fundamentally changed demographic profile of the city (c.f. Markovina 2014). The war and organised relocation of the population to places under the control of the Croatian Defence Council (HVO) ${ }^{16}$ and the Army of Bosnia and Herzegovina ${ }^{17}$ respectively brought about the polarisation of the population in the city and delineation of Mostar into the east part, where residents were mainly Bosniaks, and the west part, where Croats prevail. In this way "east Mostar" and "west Mostar" were created from one city, each of its units proclaiming national homogeneity (Puljar D’Alessio 2011:227).

The city is divided by the Bulevar hrvatskih branitelja Street $^{18}$ [engl. Boulevard of Croatian Defenders], which delineated the militarised zone during the war that nobody was allowed to cross. The memory of the ban seeped into all facets of social life and even today has an impact on the

\footnotetext{
15 The author also mentions the fourth group, namely Yugoslavs, which "disappeared" as a category after the war, since referring to Yugoslav nation was no longer desirable or suitable identification category.

${ }^{16}$ Croatian Defense Council was the highest executive and administrative body of the Croatian Republic of Herzeg-Bosnia and the main armed force of the Croats during the war in Bosnia and Herzegovina.

17 The Army of the Republic of Bosnia and Herzegovina, established primarily as a response to Serbian aggression in 1992.

${ }^{18}$ Before the war this street bore the name of the Boulevard of the People's Revolution, whereas it was given a new name in the war - the Boulevard of Croatian Defenders. The analysis of the location is beyond the scope of this paper.
} 
narrations about the space as well as the spatial tactics and routines, since crossings of the border were rare even after the war. In the spring of 1994 the zone was officially demilitarised as Mostar became united in that the urban regulations treat it as one city. However, the Bulevar has continued to represent a spatial barrier both in terms of the division into "us" and the "Others", as well as in the very specific daily practices (ibid.:228).

Inside each of the two parts of Mostar a distinctive memory politics developed, which insisted on the continuity of life and cultural, religious, and political activity of the Croatian and Bosniak population respectively, in the city and its surroundings. The integral part of memory production, which was intended to point to the difference (but also the higher value, authenticity, and a higher merit of the city belonging to a certain ethnic group) with respect to the Other part of town, was creating the collective forgetting, particularly of those episodes in history where ethnic, religious, and national affiliations of the city's residents were vague and subsumed under a monolithic category of Yugoslav identity. To that end, it was necessary to erase those history layers, which contributed to the cohesion and unity and promoted sameness within different ethnic groups in the city, from social memory. This primarily relates to the anti-fascist heritage within the city and the reminders of life during socialism.

It is precisely from the aspect of forgetting that Partisan cemetery can be considered. It was damaged by shelling and mortars during the war, but its devastation continued in the post-war period. Situated on the western side of the city, the Partisan cemetery underwent considerable physical changes after the war. It fell into disrepair, was overgrown with weeds, its pathways were littered with rubbish while some of the memorial plates were broken. The very fact that nothing much is happening in the space today, together with the observation that the residents began to avoid spending time there even during their daily Mostar walks, confirms that the memorial complex has gradually been transformed into a place of forgetting. Stone memorial plates, on which it is still possible to read the names of heroes fallen in WWII, are no longer displayed in an orderly fashion, many have been removed, and numerous have been broken. The fact that the complex is overgrown signals that the monument has been left to fall into disrepair by spatial policy makers, but also by other residents who no longer walk on 
its pathways since they do not experience the space as their own any more.

Interventions on the monument materiality show that there are individuals and groups who still go to the Partisan cemetery, often using vandalism in order to express their disagreement with the monument's initial messages, but also with the system in which the monument was created. Monument walls are defaced by graffiti, which speak volumes on the partitioning of the city in line with ethnic divisions, and dominate over the messages of unity, previously inscribed in the concept underlining this place of memory. Thus, the Partisan cemetery is at the same time a controversial space (c.f. Low and Lawrence-Zúñiga 2003:13-18), an arena where particular actors decide to do away with the reminders of the antifascist and socialist past, and earlier politics of remembering.

\section{OVERWRITING MEMORY: GRAFFITI ON THE PARTISAN CEMETERY}

Unlike the people who initiated the creation of this realm of memory, the authors of graffiti interventions on the Partiza remain anonymous. The narrative that is present in the city, which all interview partners have referred to in sharing with us their perceptions about the meaning and usages of the Partisan cemetery today, states that those who are neglecting and destroying the complex today are Mostar residents themselves, and who express their positions by graffiti.

Given that the initial task of the Mostar necropolis was to preserve the memory of the anti-fascist heritage during socialist times the Partisan cemetery, among other things, represented a means of giving legitimacy to the incumbent political system. It is this heritage that graffiti, which began to appear in the 1990s, wish to do away with both on the textual and the visual level. They are mainly written in line with the ethnic divisions, and as a response to the politics of remembering that the monument was in service of. Such interventions on the memorialisation of the overthrown systems can be considered in light of the anonimysed battle of worldviews, as is seen from the example of Croatian war graffiti by Arif Ključanin and Reana Senjković (1995:10).

What is most striking in walking through the Partisan cemetery today, are emptiness and silence, the absence of people, their voices, and 
movement in the space. Furthermore, it can be observed that no stone in the complex was left undamaged by subsequent interventions - the walls of the Partiza have been painted over and memorial plates broken and overturned. The whole promenade is covered in spray paint, mostly black. In many locations within the Partisan cemetery there are Nazi and Ustasha insignia, among which the letter U with "ears" and swastika prevail. Apart from the insignia, the walls are littered with hostile messages, especially towards Muslims, who are often designated in graffiti text as "balija" (derogatory term for Bosnian Muslims). One of the graffiti has a swastika under which numbers 14/88 are written, which are often used by neo-Nazi and racist groups. ${ }^{19}$ Such examples show that the controversial memory is being expressed as a clash of messages that the monument dedicated to anti-fascist struggle, according to its authors, initially materialised, and its subsequent overpainting with symbols containing opposite connotations.

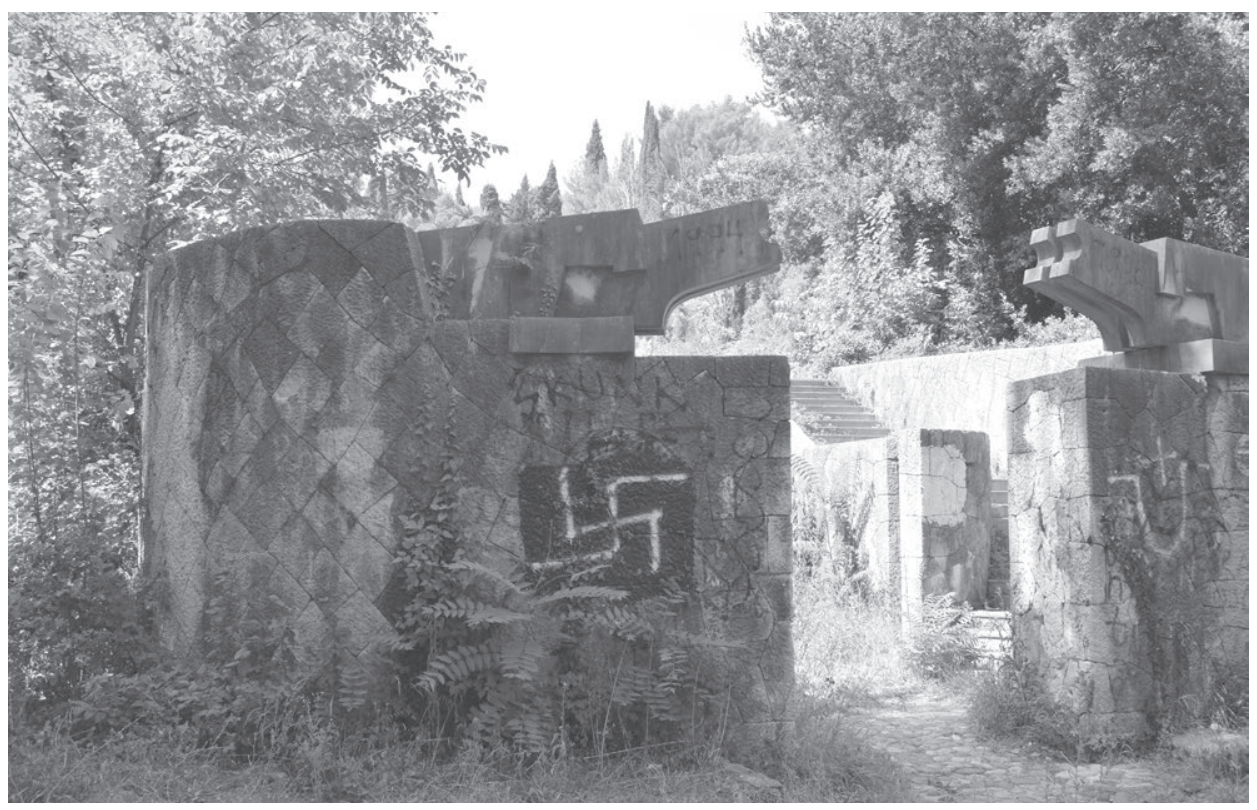

Figure 3: Entrance to the Partisan cemetery complex (Photo by Katarina Vasilj, 10/7/17)

${ }^{19}$ Number 14 refers to the sentence made of fourteen words, which talks about the preservation of the white race and ensuring the future for white children; while two eights refer to two eighth letters of the German alphabet, two letters $\mathrm{H}$, which stand for the Nazi salute Heil Hitler. 
Moreover, graffiti on the Partiza, like the one saying "THIS IS CROATIA" point to the symbolic delineations within the city and bring to the foreground the following questions: Whose is the city? Who does the space belongs to? And conversely, who is not welcome in the space? The fact that it is inscribed on the city monument, whose intention at the moment of its cultural production was to represent the unity of its residents, makes this message all the more symbolically potent.

Regarding the battle of worldviews on the Partisan cemetery walls, i.e. the expressing of opposite ideological positions with graffiti, these are not greatly represented among the inscriptions. However, graffiti "COMMUNISTS DO NOT BELONG HERE", written in black, was given a reply in red: "A COMMUNIST IS SCREWING YOUR MOTHER" (literally). Still, the contention between the worldviews is primarily evident when comparing the memory layers that the monument itself refers to with the connotations of the messages left by unknown graffiti authors.

Apart from individuals who wish to identify themselves in line with ethnic divisions with their graffiti at the Partisan cemetery, it is also noticeable that they are addressing the political elites. Thus, in several places at the site there are messages in which graffiti authors are addressing Svetozar Pudaric (SDP): "PUDARIĆ YOU'RE A CUNT", "PUDARIĆ YOU'RE A MORON" and "FUCK OFF PUDARIĆ". These red graffiti greeted Pudarić when he officially visited Mostar for the first time on 13 April 2011. At the time, in the context of recently held elections, Pudaric was the Vice President of the Federation of Bosnia and Herzegovina, and according to the media reports from that time, which were trying to provide an answer to the question as to what caused this incident, the Croatian electorate did not support or want the newly elected authorities. ${ }^{20}$ Perhaps, these are the very reasons why Pudaric was not welcome in west Mostar, perhaps they stem from the ideological disagreements, and perhaps one does not preclude the other. Pudaric laid wreaths for the fallen on the Partisan cemetery because, as he stated in his public address, they were not suitable for certain regimes. On the same day, he visited places in the Mostar surroundings where in the past the innocent were

\footnotetext{
${ }^{20}$ Available at: http://www.nezavisne.com/index/kolumne/Pudaric-u-neobranomgrozdju/86298 (accessed on 16/2/17).
} 
persecuted because they were considered unsuitable by different political systems: "Stanislav Baja Kraljević" barracks in Rodoč and the Franciscan memorial in Šroki brijeg. ${ }^{21}$ If the duration of a war is not determined by the official dates of its beginning and end, then it falls to us to determine it on a symbolic level (Ključanin and Senjković 1995:9). The example of the Partisan cemetery and the graffiti overwriting its meaning shows that the symbolic war is still raging, at least when it comes to a part of the residents. This approach to the memory clash is the one that Petra Kelemen adopts in analysing the guest books at the birth place of Josip Broz Tito (Kelemen 2006:411). Leafing through the pages where visitors to Kumrovec wrote their often politically imbued, and sometimes opposite and mutually exclusive messages, the author raises the question about all those who are absent, who do not go there to celebrate the Day of Youth, who decide not to visit Kumrovec and do not write their impressions in the guest books. We are posing a similar question while analysing the graffiti on the Partisan cemetery. The monument walls are sprayed over with words and symbols that note the positions and countermemories of those who are present. Is their content acceptable to the people who live in the city? What about the memory of the Mostar residents who did not write on the walls? What narratives and practices are closely related to the Partisan cemetery and are not exhausted by graffiti authors' messages? These and similar questions prompted us to research the perceptions about the monument among the Mostar residents who are absent.

\section{YOUNG MOSTAR RESIDENTS' MEMORIES OF THE PARTIZA TODAY}

In this chapter we shall try to shed light on the social memory of the Partisan cemetery and the events that it evokes by way of analysing the interviews conducted with Mostar residents. ${ }^{22}$ The research focuses on their

\footnotetext{
${ }^{21}$ Available at: http://www.pobijeni.info/naslovnica/clanak/384 (accessed on 16/2/17).

${ }^{22}$ In the course of the field research, we did not ask the residents about their ethnic, national, or religious affiliation since we did not consider that type of identification crucial for the analysis. Also, the interviewees themselves did not point it out during the interviews introducing themselves as "Mostar residents". This is a conscious decision, even agenda if you will, not to split our interlocutors along the lines of ethnic or religious divisions. In a similar way Stef Jansen approached his interlocutors in his study of postwar "normalization" of life in Sarajevo quarter of Dobrinja (Jansen 2015).
} 
interpretation of the urban space that they are using as well as co-creating. Key research questions that this section raises are: What does the Partisan cemetery represent to our interlocutors in modernity? Which point of the urban raster does it constitute for them? What narratives and practices are connected with it? How do they view the transformations of that space? What visions of the space and its possible usages are they creating? In this way we gain insight into the changes that the monument symbolism went through, but also into the policies that influence those changes. Our starting position is that the residents are those who are reassigning the space, but we are also focused on the factors that are channelling their interpretations.

In the analysis we were primarily interested in the younger Mostar residents' positions, namely those who do not link their own autobiographic memory with the erecting of the monument and its dynamics during the socialist period, but who the narratives about the monument's past life reach indirectly as historical memory. These are the narratives of the young, mostly highly educated people who were born right before or during the war in Mostar. ${ }^{23}$ By focusing on their perceptions, memories, and worldviews entwined with the topos of the Partisan cemetery we gain an insight into their attitudes towards the past as well as the tactics with which they interpret past events and use them to explain the city daily life in the present. This population group is viewed by the liberal arts and humanities disciplines mainly as the most prospective agents of change and potential creators of the alternative cultures of memory. ${ }^{24}$ Hence, Mitja Velikonja, a Slovenian sociologist, writes about the youth as agents of the new and different experience of history and its modern interpretations in his paper on the so-called Balkan culture in Slovenia ${ }^{25}$ (Velikonja 2002) which, as he concludes, younger generations do not treat as a remnant from the past but

\footnotetext{
${ }^{23}$ Field research that the analysis is based on was conducted towards the end of 2013. The identity of the interviewees has been protected, among other, by the use of pseudonyms.

${ }^{24}$ This interpretation cannot of course be taken as a rule since social changes can be generated in any segment of the society, which also implies any generation: thus, transgression is not necessarily linked to the younger generation - members of this group can well participate in affirming the incumbent political system.

${ }^{25}$ In his paper Velikonja writes about the popular culture on the territory of ex-Yugoslavia, which is present in Slovenia even today as a part of pop-culture.
} 
inscribe it with their own subversive, rebellious and provocative elements and manifest it as an innovation and a foundation of their self-identification (ibid.:196). However, the possibility of such adaptation of historical heritage does not preclude the appearance of nostalgia or idealised perceptions of "the golden times", which should not be understood as a reflex towards the past, or necessarily as a tendency to return to what once was, but as another way of coping with the new world organization and the modern daily life (c.f. Boym 2001).

The intertwining of the different dimensions of creating memory of the past for the needs of the present are evident in our interlocutors' narratives. Hence, the narration of our youngest interlocutor, a Mostar resident in his early twenties, shows that a nostalgic view of the city's past and the urban space "as it once was" does not exclusively belong to the older generations, who base their memory of the Partisan cemetery on autobiographical experience. Nevertheless, it is often the older residents' narrations that prompt the creation of a different image of the city and a different time among the younger residents:

"I've never seen it myself, I know from my parents' stories, etc... Literally, water from the spring and the fountain was so clean you could drink it (...). The central city park was always, always full of people. Zrinjevac, Lenjinovo, Korzo and the Partisan cemetery. My parents really, really miss it... nostalgic Mostar natives."

Although, clearly, the narrator did not witness the time when the monument lived in coexistence with Mostar residents, he is still capable of grieving for the past times and the Partiza, about which he was told by his elders. Despite remembering particular topos and the objects inside the memorial complex only indirectly (e.g. "the water from the fountain"), the content that dominates his narration, as a basis for a "different, better space", is related to the cultural practices, atmosphere, cohesion, interactions of people with the monument and with other visitors.

It was indicated in previous chapters that the cohesive character of the Partisan cemetery was ascribed to it by the author, Bogdan Bogdanović, himself. The expressions of memory that advocate the return of the cohesive dimension of the memorial complex as a potential place that connects 
different groups within the city, often crop up in narrations. Narrators repeatedly point to that character of the monument when they advocate its restoration and the revitalisation of the space, whereby they evoke the ways in which, according to their beliefs, the Partiza was used in the period before the war. However, for some narrators, the first association that a mention of the Partiza triggers is that of the 1990s war. Consequently, this is how an interlocutor, a man in his twenties, who stressed that he was a Mostar resident, but not a Mostar native, so he did not share the same memory corps with the other interlocutors when it comes to the previous usages of the city space, presented his views of the Partisan cemetery:

"- Do you know where the Partisan cemetery in Mostar is?

- Yes.

- Do you by any chance know what it represents?

- I must admit I don't.

- Do you know what it looks like?

- Yes and no. Two years ago we had a presentation there. It's a ruin.

- What associations does it evoke?

- The war. Unfortunately. Ruins everywhere - [if you] look in one direction, and turn the other way, [if you] look in yet another direction, [they are] everywhere you look. Mostar, and Sarajevo, and Banja Luka and Tuzla and Zenica..."

Evidently, the monument space is sometimes materialised also as a reference to the city's wounds and is uncovered in the overlayering of memory, so that for some narrators the episodes of history, which had a crucial impact on their experience of living the daily urban life, are in the foreground. Yet, the biggest majority of our interlocutors' narrations about the Partisan cemetery began by going further back into the past, evoking the pre-war practices of spending time in its space, regardless of the fact that many interlocutors had no personal experience of participating in them.

In some cases, remembering the different ways of using the city space, and the Partisan cemetery, particularly in the recent past, has been shaped into the awareness of the ways in which the space was manipulated by the political elite, and of the need for action through civic initiatives. Thus in 
his narrations, David, an interlocutor in his late twenties, considers the collective forgetting and disrepair of city's monuments, which celebrate the basic values of the past regime, a deliberate act on the part of the political elites. For David, the process is simultaneous and analogous to the one of erecting the monuments whose symbolic foundation rests on the ethnic group identification:

"The thing is that there is no money for this, for maintenance and security guards for the Partiza, and there is money for new dumb monuments that are in fact creating the national consciousness. One of them was erected at the new Rondo, it is dedicated to some part of HVO army. They put up two of those at the place where I live, they paved one pavement with red and white blocks, and it used to be Trg rudara before [Miners' Square] because the whole part of town is called Rudnik [The Mine] as there really was a mine underneath it, and the miners of course participated in the liberation movement so there were some busts of certain revolutionaries but they were all removed during the war. There was a specific monument dedicated to the miners who died there during a disaster that happened, and as far as I know, as I've been told, they were never taken out of the mine, so there was this monument dedicated to them. However, during the war somebody removed the monument and built a house for himself there, and the house is still there. He was never held accountable for these things. By the very act of paving all that [he means the mine, $\mathrm{AN}]$ by red and white blocks, you're showing the rest of the city that they're not welcome there. And it all comes from above, not from the people. This is imposed on us in order to create the consciousness of nationality, which we may not have had before, but are certainly going to have now."

David observes the city monuments' fate in the context of modern daily life in Mostar, especially taking into account the politics of remembering that are trying to steer it. His approach to the Partisan cemetery issue shows that he is aware of the influence on the memory creation coming "from the top down". At the same time, the narrator is resisting such influences by trying to promote the alternative cultures of remembering which wish to disassociate themselves from the dominant convention in line with which the socialist monuments are seen today. His 
approach confirms the thesis according to which we should not approach individuals, or indeed groups, who are remembering as a collective whose minds can be subjected to endless manipulation through the mechanisms of the politics of remembering (Sorabji 2006:2; Škrbić Alempijević 2009:9).

Likewise, in other narratives of the young people we interviewed about the Partisan cemetery today, the neglect and devastation of the memorial complex are presented as a problem that reflects the broader social context and relationships in the city, and indeed the whole country. However, their thoughts on who is responsible for the present treatment of the city space, and who should take care of the Partiza differ. Hence, Asja, a twenty-three-year-old expresses the same wish as David to have the Partisan cemetery cleaned so that it can become a representative Mostar space once again. When it comes to the "culprits", this narrator identifies ordinary Mostar residents since she believes that ideological divisions should not be used as an excuse for being neglected by the residents. The persons Asja holds responsible for the situation with the monuments are young "people with problems" who use the Partisan cemetery as a site for boisterous parties. During the interview she stressed her connection with Mostar, and in her narrations the term denoted people, Mostar residents, regardless of their nationality. Also, she contrasted the attitudes of the residents, especially younger, towards the Partisan cemetery with the urban spaces in general by using the conventional media representation of the division of the city:

"Disorder occurred because this is the place where young people get drunk and even take soft drugs. (...) In that state, of course, there are more frequent outbreaks of disorder brought about by temporary insanity due to intoxication that they experience at the moment, I want this to change. I think that over the years we've overcome this and I think whoever is true Mostar resident at heart, they love the monument and wish to see it restored, simply out of pure love for Mostar". 


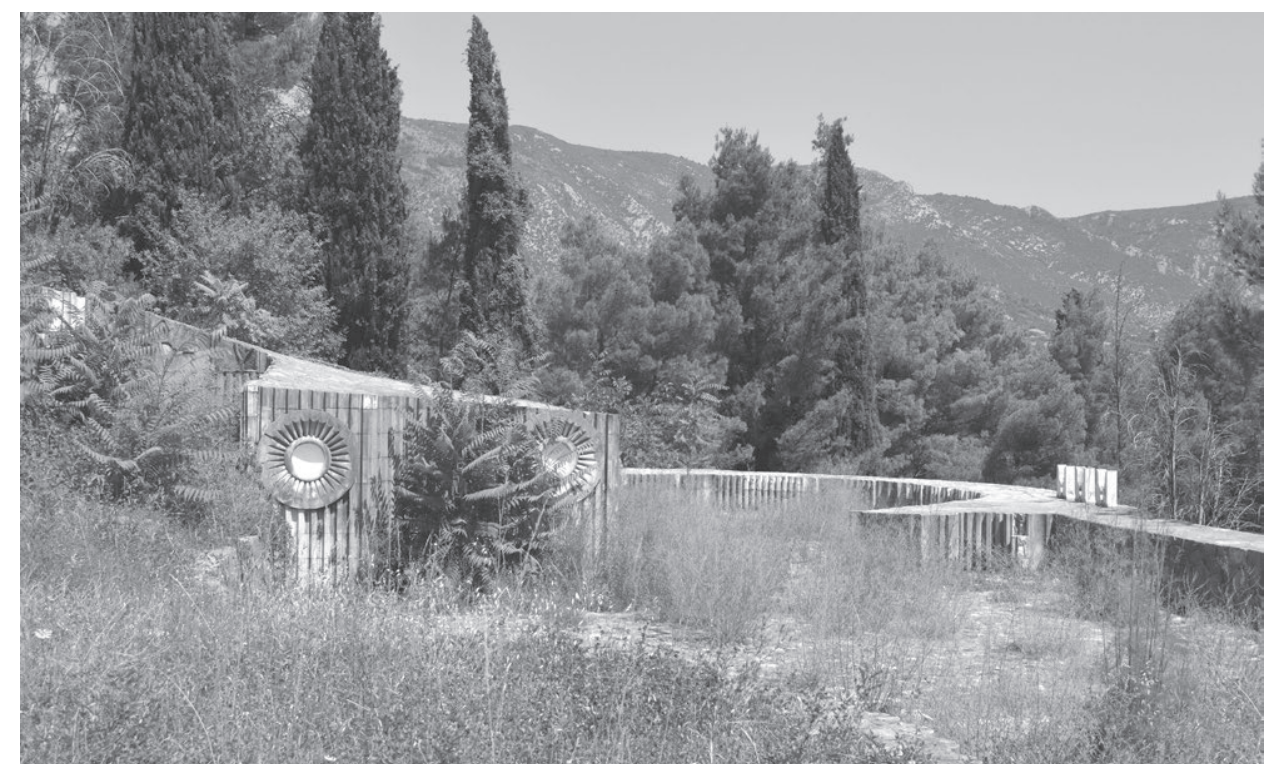

Figure 4: Neglected landscape of the Partisan cemetery (Katarina Vasilj, 10/07/17)

In her narrations, Asja disassociates herself from the dominant interpretation of Mostar as a hopeless city or a victim city, trying to give an active role to the Mostar residents in defining their city and the relationships in it differently, namely the possibility of action beyond the national divisions and conflict perpetuation. She interprets her suggestion that Mostar residents themselves should approach the Partiza differently in light of the fact that "Mostar can do better".

The opinion that was constantly repeated in the narrations by all the people we interviewed on the topic of the Partisan cemetery, was that the site ought to be restored, protected, and made an integral part of the city daily life, in the daytime and not only by night. Namely, the majority of our interlocutors see the Partisan cemetery today as a destination for young people's night life, and as they stated, a "place where drinking goes on". Some of the interviewees underline the discrepancy between the past usages of the memorial complex which, in their opinion, gave the site certain dignity and the significance of the place of memory, and the ones of today which are mostly devoid of the memory dimension. Consequently, some interlocutors, while advocating the monument restoration, emphasise that in order for the 
revitalisation of that space as a place of memory to happen, it is crucial for the practices and daily routines taking place at the site to change. A twentythree-year old interviewee explains this position in the following way:

"[It is] a beautiful monument in the city of Mostar which has unfortunately become overshadowed and is exclusively used by young people to get drunk during the evening hours. I used to drink there but I wish it weren't so, [I wish] it were restored so that it can represent a tourist attraction that it really is because it is a really beautiful monument, but unfortunately it is not appreciated and the majority of people don't actually know when it was created or why, nor do they pay enough attention to it".

Unlike the above mentioned narrator, David and Jelena do not see any problem with the way the Partisan cemetery is being used by young people at night - they are more concerned with the issues of its non-use and neglect. In their opinion any use of the space is better and more beneficial than total ignorance, avoidance, and forgetting, which is confirmed by David's account:

"It doesn't matter that there's drinking. What is important is that it becomes a part of our landscape and that we simply accept it as a part of Mostar, regardless of the fact that it wasn't represented to us like that".

\section{CONCLUSION}

The narrations of young residents of Mostar about the wartime and post-war changes of the space mainly point to the Partisan cemetery representing an ambivalent space in the dominant discourse. It is a location that has been overthrown from its pedestal of national and city memory, a small corner from which the traces of past performative memory have been erased. The space has not been given an architectural makeover under the dictate of newly established relationships of power in the city and the country, which would reflect the current systems of cultural values and the memory matrix. Moreover, this city site is rarely mentioned in the official rhetoric today. Thus on the level of the dominant discourse, so far the Partisan cemetery has not been given the opportunity to fulfil different politics of 
remembering nor is it open for other place experiences which would not boil down to its interpretation exclusively as a "socialist monument", but also as a "monument to socialism". We believe that the very impossibility on the part of the political and social elites to see this space beyond the label (and the stigma) of the "socialist", anchors this memory place firmly in the past, depriving it of any alternative imagining, reshaping, and uses in line with the present moment and its needs. Therefore, the memorial complex is being transformed into a materialization of forgetting. As Paul Connerton shows, in describing different types of forgetting, silence, not speaking about what we remembered before, planned obsolescence, as well as neglecting previous places of memory, do not represent an oversight nor reflect passivity - they are very active acts of forgetting (Connerton 2008).

As a consequence of forgetting, on the level of the spatial planning policies, namely the site falling into disrepair, its exclusion from the city protocol events and public events, the location, due to its neglect, disrepair and defacing, is avoided even in Mostar residents' daily walks through their city. At the same time, it ceases to be a political and tourist destination. Due to the absence of people in the space and the non-presence of the site in their mental maps, the forgetting of the memory place has become a part of urban daily life. Since the people are absent from the space, in our research, by way of targeted interviews, we attempted to encompass the Mostar residents' narrations in order to see how much the space, seeing as it was no longer used as a place of daily practices, is being realised as a part of their perceptions about the city. Our analysis confirmed once again that the persons and social groups who do not have direct experience of living in a certain period of history, can still have very firm positions about it and can create vivid narratives. At the same time, they can consider the places of memory without being burdened by the past. Nevertheless, the questions that our interlocutors ask themselves, about how far and in what ways the space should be revitalized, what meanings and practices should be inscribed in it, so far remain without specific answers, and more to the point, without any response in the city of Mostar's spatial planning policies.

Finally, the problem with the creation of a landscape of forgetting in Mostar, in the space adjacent to which (but not in which) the urban daily life goes on continuously, raises additional questions: what that 
process means for the city, what it is telling us about the city, its policies and cultures, and what consequences it has for the residents. Numerous studies of the places of memory interpret the evocations of the images from the past as mechanisms in creating apparent continuity from a long line of discontinuity, and their spatialisation as a material reminder of that continuity, a tangible link between past and present (c.f. Nora 1996). Contrary to this, the Partisan cemetery in Mostar is a materialisation of discontinuity, the attempt of city (as well as regional and state) politics to do away with the socialist past, and the ambivalent attitudes towards the value systems and interethnic relations that were present before the independence of Bosnia and Herzegovina. It is a site where cutting ties with the past is made visible. Consequently, just as the Partisan cemetery can function as a place of remembering the National Liberation War and the meanings that the topos had in Yugoslav politics of remembering, for some other social actors, individuals, and groups, it is a reminder of the events from the 1990s and of the division of Mostar. Nonetheless, when it comes to the possibilities and ways of overcoming the divisions, which many of our young interview partners, who agreed to share with us their visions of the memorial complex and the city as a whole, advocate, both the Partisan cemetery and practices related to it remain silent.

\section{REFERENCES}

BOGDANOVIĆ, Bogdan. 1988. Mrtvouzice: mentalne zamke staljinizma. Zagreb: August Cesarec.

BOGDANOVIĆ, Bogdan. 2001. Grad i budućnost. Zagreb: Naklada Mlinarec-Plavić.

BOGDANOVIĆ, Bogdan and Nataša JOVIČIĆ. 2002. Apsolutno paf: razgovori. Zagreb: Meandar.

BOYM, Svetlana. 2001. The Future of Nostalgia. New York: Basic Books.

CIPEK, Tihomir. 2007. "Kultura sjećanja i politika nacionalnih identiteta". In Kultura sjećanja: povijesni lomovi i svladavanje prošlosti, eds. Tihomir Cipek and Olivera Milosavljević. Zagreb: Disput, 7-10.

CIPEK, Tihomir and Sulejman BOSTO. 2009. "Predgovor: 1945. godina: nagovještaj nade, posljedice i podijeljena sjećanja". In Kultura sjećanja 1945: povijesni lomovi $i$ svladavanje prošlosti, eds. Tihomir Cipek and Sulejman Bosto. Zagreb: Disput, 7-11.

CONNERTON, Paul. 2008. “Seven types of forgetting”. Memory studies, vol. 1/1:59-71. https://doi.org/10.1177/1750698007083889 
CONNERTON, Paul. 2009. How Modernity Forgets. Cambridge: Cambridge University Press.

ČAPO, Jasna and Valentina GULIN ZRNIĆ. 2011. “Oprostornjavanje antropološkog diskursa: od metodološkog problema do epistemološkog zaokreta". In Mjesto, nemjesto: interdisciplinarna promišljanja prostora $i$ kulture, eds. Jasna Čapo and Valentina Gulin Zrnić. Zagreb: Institut za etnologiju i folkloristiku ; Ljubljana: Inštitut za antropološke in prostorske študije, ZRC SAZU, 9-65.

FRYKMAN, Jonas. 2004. "Making Sense of Memory: Monuments and Landscape in Croatian Istria”. Ethnologia Europaea, vol. 33/2:107-120. https://www.mtp.dk/ cgibin/PDFmedopenaccess/Making_Sense_of_Mem_0_0_9788763502382.pdf (accessed February 16, 2017).

ILIĆ, Kristina. 2016. Povijesna i kulturnoantropološka analiza hrvatsko-bošnjačkih sukoba u Mostaru (1992 - 1995). MA thesis. Zagreb: Filozofski fakultet Sveučilišta u Zagrebu.

JANSEN, Stef. 2015. Yearnings in the Meantime. 'Normal Lives' and the State in a Sarajevo Apartment Complex. New York - Oxford: Berghahn Books.

KELEMEN, Petra. 2006. "Tko će dobiti bitku na ovim stranicama: tekstovi iz knjige utisaka u Titovoj rodnoj kući”. In O Titu kao mitu, eds. Nevena Škrbić Alempijević and Kirsti Mathiesn Hjemdahl. Zagreb: Srednja Europa, 399-418.

KLJUČANIN, Arif and Reana SENJKOVIĆ. 1995. Hrvatski ratni grafiti. Zagreb: ZRIšport ; Zadar: ZADIZ.

LEBOŠ, Sonja. 2012. Bogdan Bogdanović - ukleti neimar. Exhibition catalogue. Zagreb: Gliptoteka HAZU.

LONČAR BUTIĆ, Nataša. 2012. "Diskusija nakon 1. sesije izlaganja”. In Akteri društvenih promjena u prostoru: transformacija prostora i kvalitete života $u$ Hrvatskoj, eds. Anđelina Svirčić Gotovac and Jelena Zlatar. Zagreb: Institut za društvena istraživanja u Zagrebu, 63-66.

LOW, Setha M. and Denise LAWRENCE-ZÚÑIGA. 2003. "Locating Culture”. In The Anthropology of Space and Place: Locating Culture, eds. Setha M. Low and Denise Lawrence-Zúñiga. Oxford - Malden, MA: Blackwell Publishing, 1-48.

MARKOVINA, Dragan. 2014. Između crvenog i crnog: Split i Mostar u kulturi sjećanja. Zagreb: Plejada ; Sarajevo: University Press.

NORA, Pierre. 1996. Realms of Memory. The Construction of the French Past, vol. 1. Conflicts and Divisions. New York: Columbia University Press.

PULJAR D’ALESSIO, Sanja. 2011. "Projekcija simboličkih prostora u sporna mjesta: Mostar". In Mjesto, nemjesto: interdisciplinarna promišljanja prostora i kulture, eds. Jasna Čapo and Valentina Gulin Zrnić. Zagreb: Institut za etnologiju i folkloristiku; Ljubljana: Inštitut za antropološke in prostorske študije, ZRC SAZU, 227-242. 
RIHTMAN-AUGUŠTIN, Dunja. 2000. Ulice moga grada. Beograd: Biblioteka XX vek.

SORABJI, Cornelia. 2006. "Managing Memories in Postwar Sarajevo: Individuals, Bad Memories, and New Wars". Journal of the Royal Anthropological Institute, vol. 12/1:1-18. https://doi.org/10.1111/j.1467-9655.2006.00278.x

ŠKRBIĆ ALEMPIJEVIĆ, Nevena. 2009. Priručnik za kolegij Antropologija društvenog sjećanja. Zagreb: Filozofski fakultet Sveučilišta u Zagrebu.

VELIKONJA, Mitja. 2002. "Ex-Home: 'Balkan culture' in Slovenia after 1991”. In Cultural Boundaries in Europe: The Balkans in focus, eds. Sanimir Resic and Barbara Törnquist-Plewa. Lund: Nordic Academic Press, 189-207.

\section{INTERNET SOURCES}

ABRAŠMEDIA. 2011. "Partizansko groblje". YouTube, February 11. https://www. youtube.com/watch?v=eDZZoitB-30 (accessed February 16, 2017).

BAČIĆ, Mašenjka. 2013. “'Ukleti neimar': 'Socijalistički modernizam imao je humanističku viziju da se stvari grade kako bi ljudi živjeli bolje i dostojanstvenije"”. Lupiga.com, September 24. http://www.lupiga.com/vijesti/uz-ukletog-neimarasocijalisticki-modernizam-imao-je-humanisticku-viziju-da-se-stvari-grade-kakobi-ljudi-zivjeli-bolje-i-dostojanstvenije (accessed February 16, 2017).

"Bogdan Bogdanović: Sanjam o svijetu bez spomenika". Razgovor vodio Drago Bojić. 2014. Prometej.ba, January 8. http://www.prometej.ba/clanak/kultura/bogdanbogdanovic-sanjam-o-svijetu-bez-spomenika-1411 (accessed February 16, 2017).

KEGELJ, Ivan. 2013. "Bogdan Bogdanović: Mostarski grad mrtvih i Mostar - mrtvi grad". Lupiga.com, February 17. http://lupiga.com/vijesti/bogdan-bogdanovic-mostarskigrad-mrtvih-i-mostar-mrtvi-grad (accessed February 16, 2017).

LIPOVAC-JANDRIĆ, Aldina, ed. 2015. "Partizanski spomenik - 'Mostar u malom, replika grada na Neretvi"”. Impulsportal.net, September 26. http://impulsportal.net/ index.php/kolumne/drustvo/919-partizanski-spomenik-mostar-u-malom-replikagrada-na-neretvi (accessed February 16, 2017).

"Pudarić: Ovo nije provokacija nego ljudska gesta i počast žrtvama". 2011. Stopama pobijenih, April 14. http://www.pobijeni.info/naslovnica/clanak/384 (pristup 16. 2. 2017.).

RADIO SLOBODNA EVROPA. 2012. "Dvadeset godina poslije -- 10". YouTube, March 26. https://www.youtube.com/watch?v=7aAVVrfqHvo (accessed February 16, 2017).

SPAJIĆ-PERIĆ, Kristina. 2011. "Pudarić u neobranom grožđu”. Nezavisne novine, April 14. http://www.nezavisne.com/index/kolumne/Pudaric-u-neobranomgrozdju/86298 (accessed February 16, 2017). 
Kristina Ilić

Nevena Škrbić Alempijević

\section{KULTURE SJEĆANJA, KRAJOLICI ZABORAVA: PRIMJER PARTIZANSKOG GROBLJA U MOSTARU}

Ovaj se članak bavi materijalizacijama sjećanja kojima se pristupa kao važnim sastavnicama politika pamćenja. Naglasak je pritom na spomenicima kao objektima koji se proizvode u skladu s aktualnim društvenim trenutkom kako bi se poželjno sjećanje na odabrane povijesne epizode od nacionalnog značenja upisalo u prostor i učinilo dijelom svakodnevice. Komunikacija između materijalnosti u prostoru i ljudi koji joj pridaju ili oduzimaju značenje ključ je etnološkog i kulturnoantropološkog proučavanja spomenika. Temeljno pitanje koje se ovim radom problematizira glasi: što se događa s materijalizacijama sjećanja na onu prošlost koja, promjenom političkog poretka, više ne predstavlja jedan od simboličkih temelja države te, u novim okolnostima, postaje marginalnom i nepodobnom? Procesi koji se tada zapažaju u prostoru mogu se definirati kao tvorba krajolika zaborava.

Navedena se pitanja osvjetljavaju na primjeru spomeničkog kompleksa Partizansko groblje, autora Bogdana Bogdanovića, koje je podignuto u Mostaru 1965. godine kao spomen na borbu za oslobođenje grada protiv njemačkog Wehrmachta. Dok je ovaj spomenik u socijalističkoj prošlosti Bosne i Hercegovine, u skladu s ondašnjom ideologijom, predstavljao značajno spomen-mjesto vezano uz Narodnooslobodilačku borbu, tijekom ratnih događanja u devedesetim godinama prošlog stoljeća potonuo je u kolektivni zaborav. Zbog zapuštenosti i devastiranosti, Partizansko groblje pretvara se u mjesto na kojem rez sa socijalističkom prošlošću postaje vidljivim.

Dinamički odnos političkih strategija, spomeničke baštine grada Mostara i građana u različitim razdobljima promatra se višeglasno, pri čemu se nastoji prikazati kontekst nastanka, ali i suvremenog (ne)korištenja spomeničkog kompleksa. Iz toga se razloga istraživanju pristupilo primjenom različitih kvalitativnih metoda, pri čemu se primat daje terenskom radu: promatranju ljudskih praksi na samom Partizanskom groblju te intervjuima sa stanovnicima Mostara. Naracije mlađih Mostaraca upućuju na to da se ova lokacija može promatrati i onkraj etničkih podjela u gradu i državi te da i dalje predstavlja bitnu točku u mentalnim mapama građana.

Ključne riječi: kulture sjećanja, krajolici zaborava, socijalistički spomenici, Mostar, Partizansko groblje

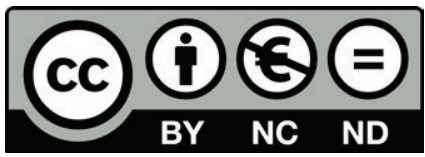

Articles published in this journal are Open Access and can be distributed under the terms and conditions of the Creative Commons license Attribution-NonCommercial-NoDerivatives 4.0 (http://creativecommons.org/licenses/by-nc-nd/4.0/) 